International Journal of Heritage, Tourism and Hospitality Vol. (12), No. (1/2), March, 2018

By: Faculty of Tourism and Hotels, Fayoum University

\title{
The Effect of Fellow Workers' Warmth and Competence on Frontline Employees' Proactive Customer Service Performance and Turnover Intentions in Hotels
}

Yasser Abd El-Aty Amr Deraz

Faculty of Tourism and Hotels, Sadat City University

\begin{abstract}
The warmth and competence represent two fundamental social dimensions that people often use to evaluate other individuals or groups. In terms of proactive customer service performance (PCSP), it is still a relatively recent concept; and its antecedents are unidentified to a great extent. Therefore, understanding how warmth and competence influence PCSP will add to the knowledge of the hotel industry, both theoretically and practically. Thus, the study aimed at investigating employees' perceptions of fellow workers' warmth and competence as well as measuring employees' PCSP and turnover intentions in hotels. In addition, the study also examines the impact of fellow workers' perceived warmth and competence on employees' PCSP and turnover intentions. For achieving these objectives, data were collected using questionnaires. From all five-star hotels (33 hotels) in Cairo, only 10 hotels that represent about $30.3 \%$ accepted to distribute the questionnaire to their employees. A questionnaire form was developed based upon the relevant review of literature and a pilot study which was conducted on the ten investigated hotels. According to this pilot study, there were 500 frontline employees (e.g. front desk agents, food servers, and bartenders) working in these hotels. Therefore, it was possible to distribute the questionnaire forms to the entire population as it was of a manageable size. Only 370 valid questionnaire forms were received from the respondents. To analyze these forms, descriptive analysis, correlation analysis, and multiple regression analysis were used. The findings showed that co-workers' warmth was perceived low by employees, whereas fellow workers' competence was perceived high. Moreover, co-workers' perceived warmth had a negative effect on employees' PCSP and turnover intentions. In addition, competence had a positive effect on employees' PCSP and a negative effect on turnover intentions. Thus, the results suggested that hotels should focus on increasing co-workers' perceived warmth but they should work hard to reduce the negative impact of the perceived warmth through the permanent management supervision of employees when providing service to customers. Furthermore, hotel management should also maintain the high competence of the frontline employees as well as it should try to increase it.
\end{abstract}

Keywords: Social perceptions; perceived warmth; perceived competence; proactive customer service performance; turnover intentions; frontline employees.

\section{Introduction}

Frontline employees have regular face-to-face or voice-to-voice contacts with customers. Therefore, they play a vital role on the survival and success of hospitality organizations. Actually, frontline hotel employees provide a lot of information about customers' requests, complaints, and expectations to hotel management (Tracey and Tews, 2004; Kim et al., 2006; Chiang and Jang, 2008; Kim, et al., 2009; Karatepe, 2013).

Warmth refers to employees' personal characteristics (e.g. friendliness, helpfulness, sincerity, trustworthiness, empathy, and kindness). On the other hand, competence is the extent to which employees effectively fulfill goals and involves traits, such as intelligence, skill, creativity, and efficacy (Abele et al., 2008; Cuddy et al., 2008). Warmth and competence are vital elements to socially evaluate individuals and groups (Fiske et al., 2002; Wojciszke 2005a, 2005b).They are the two main socio-cognitive dimensions that people often use to explain behavior or form judgments of others (Fiske et al., 2002; Bufquin et al., 2017). They are necessary to perceptions 
of humanness (Harris and Fiske, 2009). They are so widely used that when people have to describe other individuals or groups, over $75 \%$ of their impression formations are likely to fall under the warmth and competence constructs (Wojciszke, 1994; Cuddy et al., 2011).

Warmth and competence have been studied in numerous fields and environments comprising sociology, socio-psychology, and marketing (Wojciszke, 1994; Fiske et al., 2007). In contrast, despite the importance of these two dimensions, they have received little research attention in the field of organizational behavior (Cuddy et al., 2011). Few hospitality researches have examined the influence of warmth and competence in the work-place (e.g., Bufquin et al., 2017).

In terms of PCSP, researches of employees' behaviors have gone beyond service-oriented behaviors (Chuang and Liao, 2010). It has become essential to investigate the frontline employees' PCSP because hotel business relies on them to meet customers' needs (Raub and Liao, 2012; Bowen, 2016). In addition, as PCSP is still a relatively recent concept, its antecedents are unidentified to a great extent. Therefore, understanding how warmth and competence influence PCSP will add to the knowledge of the hotel industry, both theoretically and practically. Thus, the objectives of this study is to assess the effect of social perceptions (warmth and competence), as held by employees as related to their fellow workers, on employees' PCSP and turnover intentions.

\section{Literature review}

\section{Warmth and competence perceptions}

Warmth and competence judgments in organizations have effects on important human resources issues, such as hiring decisions, role and task assignments, performance evaluations, and assessments of teams' performance (Cuddy et al., 2011). Warmth and competence are combined to generate four identifiable quadrants, which are high warmth/high competence; low warmth/low competence; low warmth/high competence; and high warmth/low competence (Fiske et al., 1998; Fiske et al., 2002; Fiske et al., 2006).

Social perceptions have been extensively studied and have received sufficient attention in academic literature since the 1940s and 1950s (Asch, 1946; Bales, 1950; Allport, 1954). Asch (1946) discussed in his person perception research the two central traits that personality impression formation often includes, i.e. warm-cold versus competence. Similarly, Bales (1950) was the earliest researcher distinguishing between socio-emotional (warmth-oriented) and task (competence-oriented) leadership. A few years later, Allport (1954) confirmed that both single individuals and social groups could be perceived as warm and incompetent. Afterwards, Rosenberg et al., (1968) indicated that perceptions of others are classified into two dimensions: intellectual good/bad and social good/bad. Subsequently, other researchers referred to the two dimensions (warmth and competence) with alternative names: self-profitable traits, such as confident and intelligent as opposed to other-profitable traits, e.g. tolerant, trustworthy (Peeters and Czapinsky, 1990); competence in contrast with morality (Wojciszke, 2005a; Leach et al., 2007).

Further research on the dimensionality of social perceptions led to creating the Stereotype Content Model (SCM) by Fiske et al., (2002), which applied the two dimensions (warmth and competence) to perceptions of groups. According to SCM, warm social groups do not vie with the in-group for the same resources, such as college space, whereas they are perceived as competent if they are high in status, such as economically successful groups (Kassin et al., 2011). Later, Cuddy et al., (2007) developed the BIAS map (Behaviors from Intergroup Affect and Stereotypes), which is an extension of SCM. The BIAS map exhibits the way in which warmth and competence perceptions form emotions and behaviors in social reciprocal actions (Cuddy et 
al., 2007; Fig. 1). The vertical axis of the diagram represents high or low warmth, while horizontal axis illustrates high or low competence. Emotional reactions are depicted by the lighter arrows, whereas behavioral responses are represented by the dark arrows within Fig. 1.

Figure 1: Behaviors from Intergroup Affect and Stereotypes Map.

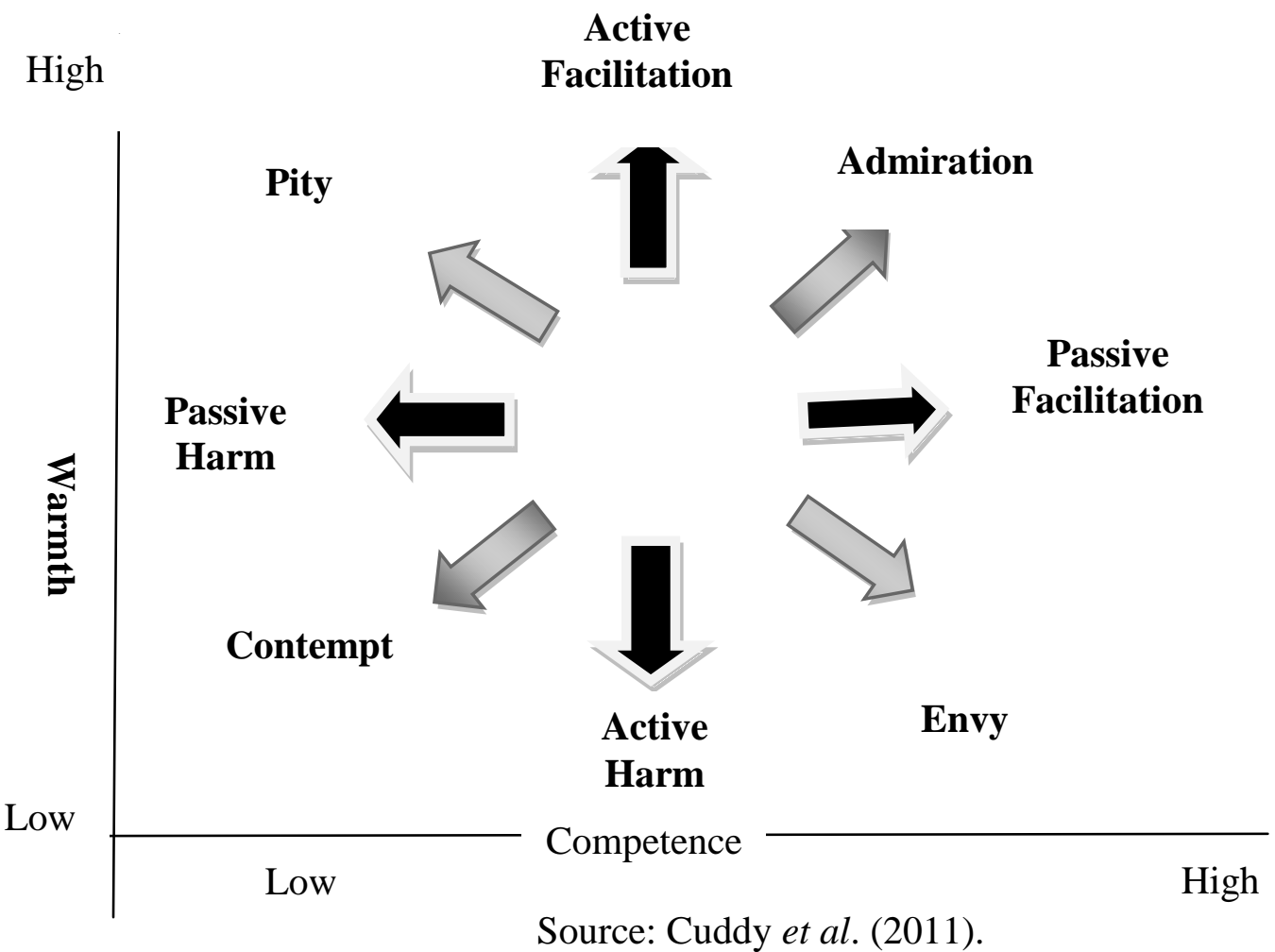

According the BIAS map, warmth and competence are combined to generate four unique emotional responses: admiration, contempt, envy, and pity (Caprariello et al., 2009; Cuddy et al., 2011). Admiration is concerned primarily with high-status, noncompetitive groups that are perceived as warm and competent. Contempt is concerned with low-status, competitive groups seen as incompetent and cold. Envy is concerned with high-status, competitive groups perceived as competent but cold. Finally, pity is concerned with low-status, noncompetitive groups perceived as warm but incompetent (Cuddy et al., 2011).

Moreover, The BIAS map shows four different patterns of behavioral responses derived from the combination of high versus low warmth and competence: active facilitation (e.g. helping), active harm (e.g. harassing), passive facilitation (e.g. convenient cooperation), and passive harm (e.g. neglecting) (Cuddy et al., 2007).

To survive in the social world, people need to find out whether others intend to harm or benefit them (warmth), and they also need to assess others' capability to carry out those intentions (competence) (Fiske et al., 2007). The warmth dimension includes two different aspects, namely sociability and morality (Leach et al., 2007). Persons or groups are perceived as warm if they normally exhibit social and moral behaviors and if they have good intentions and do not endanger others (Fiske et al., 2007). Warm people are usually considered as empathetic and understanding, and typically demonstrate caring for others (Abele et al., 2008). Warmth also involves cooperation among individuals and building strong relationships with others (Leach et al., 2007). 
On the contrary, competent people are considered to be more independent and more individualistic. Moreover, they are able to perform their tasks well and have a tendency to lead and control other people (Abele et al., 2008; Bufquin et al., 2017). Competence captures characteristics that are typically associated with the ability, such as intelligence. Thus, warm persons are considered to be more socially-oriented, while competent people are more taskoriented (Cuddy et al., 2011).

\section{The primacy of warmth judgments}

Although warmth and competence appear consistently, a substantial body of research (e.g., Wojciszke et al., 1998; Wojciszke and Andrea, 2008) shows that warmth is the primary dimension. It is judged more quickly than competence, and it is weighted more heavily when evaluating others (Cuddy et al., 2007). The primacy of warmth is acceptable because of the urgency with which people need to judge a strange others' warmth (Peeters, 2001). Additionally, warmth traits tell perceivers about the other person's intention for good or bad that is important to survival (Wojciszke, 2005a). Moreover, moral-social characteristics help or hinder others, while competence characteristics help or hinder primarily the self (Fiske et al., 2002).

However, competence may be more important than warmth because the weights given to each dimension are, to some degree, context-sensitive. For example, competence is weighted more heavily when the self and related others are evaluated (Abele and Wojciszke, 2007; Wojciszke and Andrea, 2008). People prefer for themselves and closely related others to have the traits that are beneficial to the self (i.e. competence) than the traits that profit others (i.e. warmth). Also, in organizational contexts, competence appraisals may take primacy. For instance, a job description may focus entirely on an applicant's competence when deciding to employ people (Cuddy et al., 2011).

\section{Proactive customer service performance}

PCSP refers to individuals' "self-started, long term-oriented, and persistent service behavior that goes beyond explicitly pre-scribed performance requirements" (Rank, et al., 2007, p. 366). Such behavior is different from task performance, because it exceeds the established job description and written standard operating procedures of service ((Rank et al., 2007; Raub and Liao, 2012). PCSP includes three main aspects (Zhu et al., 2017). First, it encompasses self-initiated behaviors, including taking initiatives to improve service by providing suggestions to clients and trying to increase customers' satisfaction by offering service "extras". Employees elicit PCSP of their own rather than waiting to be informed by customers or supervisors to do so. Second, it entails long-termoriented behaviors, e.g. anticipating customers' needs, improving oneself to be capable of dealing with future challenges, and presenting forward thinking behaviors. Third, it involves persistent behaviors, such as consistently fulfilling customer needs and expectations and proactively requesting feedback from customers (Rank et al., 2007; Raub and Liao, 2012).

\section{Employee turnover intention}

Turnover intention is defined as an employee's intention to quit the organization and the tendency to seek employment in another organization (Jung et al., 2011; Jung, 2014). This intention may be recognized when staff speak unenthusiastically about their jobs, when they poorly take part in the organization, or when they in actual fact quit their jobs (Jang and George, 2012; Karatepe, 2013). Employee turnover is defined as "the voluntary and involuntary permanent withdrawal from an organization" (Robbins and Judge, 2007, p. 72). Staff turnover is seen to be extremely high in the hospitality organizations (Birdir, 2002; Kennedy and Berger, 1994; Yang et al., 2012). 
Employee turnover has been classified into two categories: voluntary turnover and involuntary turnover (Albattat and Som, 2013). The former occurs when employees ask to end their relationships with the employer because of several reasons, such as salary, benefits, relationship with management and other employees, working hours, and transport difficulties. On the other hand, the latter happens when staff depart the organization unwillingly due to retirement, illness, death, pregnancy, and leaving the area (Lashley, 2001; Lam et al., 2003). Employee turnover can lead to a degradation of organizational performance as a whole, a loss of employee expertise, the reduction of employees' job satisfaction, increment of staff training costs, etc. (Cho et al, 2009)

Figure 2: Hypothesized model

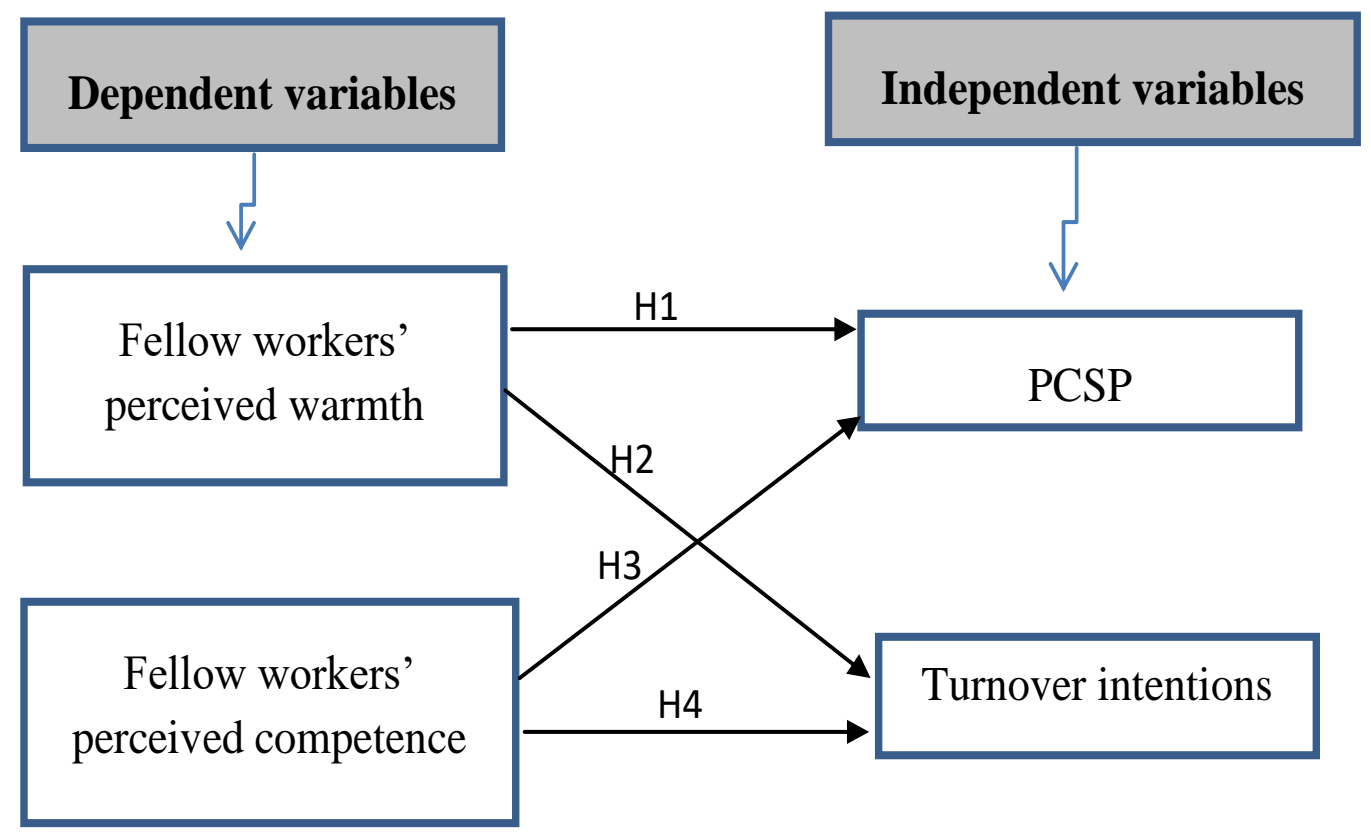

Based on the abovementioned literature, this research proposes the following hypotheses and exhibits them in the previous model above (see Fig. 2):

Hypothesis 1. Fellow workers' perceived warmth positively affects employees' PCSP. Hypothesis 2. Fellow workers' perceived warmth negatively affects employees' turnover intentions.

Hypothesis 3. Fellow workers' perceived competence positively affects employees' PCSP.

Hypothesis 4. Fellow workers' perceived competence negatively affects employees' turnover intentions.

\section{Research methodology}

Based on the literature review, this study assesses four variables: two independent variables (i.e. co-workers' perceived warmth; co-workers' perceived competence) and two dependent variables (i.e. PCSP; turnover intentions). In addition, the research examines the effects of the first two variables on PCSP and turnover intentions.

\section{Measurement and instrument}

The questionnaire was developed from previously tested survey instruments for the purpose of proving the previously suggested hypotheses. It is composed of four main parts: perceived warmth, perceived competence, PCSP, and turnover intentions. The questionnaire items related 
to the perceived warmth and competence of fellow workers were obtained from a study by Bufquin et al. (2017) because the competence construct in this study had a Cronbach's alpha value of 0.895 ; while the warmth construct had an alpha value of 0.916 . These two constructs were also used by Fiske et al. (2002) who found that, the competence and warmth constructs had Cronbach's alpha values of 0.90 and 0.82 , respectively. The competence construct encompassed five characteristic features (i.e. competent, intelligent, independent, confident, and competitive); while the warmth construct included four characteristic features, i.e. sincere, good-natured, warm, and tolerant (Fiske et al., 2002; Bufquin et al., 2017).

The questionnaire items for the construct of PCSP were taken from previous studies (Rank et al., 2007; Raub and Liao, 2012; Lau et al., 2017) because these studies found that the Cronbach's alpha coefficients of the aforementioned construct was above the 0.70 level suggested by Nunnally and Bernstein (1994). PCSP had four items, including such statements as "I use my own judgment and understanding of product problems to determine when to make exceptions of improvise solutions," "I create partnership with other service representatives actively to better serve customers," "I take the initiative to communicate client requirements to other service areas and collaborate in implementing solutions," and "I check with customers proactively to verify that customer expectations have been met or exceeded."

To measure turnover intentions, three items from Singh et al. (1996) and Bufquin et al. (2017) were used, consisting of such statements as "It is likely that I will actively look for a new job," "I often think about quitting," and "I will probably look for a new job." In their researches, the turnover intentions construct achieved a Cronbach's alpha value of 0.79 and 0.916 , respectively. Responses for all four constructs (i.e., perceived warmth, perceived competence, PCSP, and turnover intentions) were based on a 5-point Likert-type scale, ranging from 1 (completely disagree) to 5 (completely agree). Lastly, the questionnaire included demographic questions related to gender, age, and education.

\section{Population and sample}

The target population for the study was frontline employees of all five-star hotels (33 hotels) in Cairo (Egyptian Hotel Guide, 2016). Only 10 five-star hotels that represent about $30.3 \%$ accepted to distribute the questionnaire to their employees. The main reason for choosing this category of hotels is that, the concepts of warmth, competence, and PCSP are applied, therefore they can be measured. Also, these types of hotels are managed by international hotel chains or franchised. Thus, when the research is conducted on these hotels, the results obtained will be obvious and can then be applied on the other categories of hotels (i.e. three or four-star hotels). According to the pilot study conducted on the ten investigated hotels, there were 500 frontline employees working in frontline departments (e.g., front desk agents, food servers, and bartenders). Therefore, it was possible to distribute the questionnaire forms to the entire population as it was of a manageable size. Only 370 valid questionnaires were received, representing a response rate of 74 percent. The questionnaire forms were distributed and collected by hand to the investigated sample of employees during period from 7-2017 to 9-2017.

\section{Reliability and validity}

This research uses the coefficient of Cronbach's alpha to compute the reliability. The reliability of the instrument is acceptable when Cronbach's coefficient alpha value is higher than .7 (Pallant, 2007). The study tests indicate high internal consistency (coefficient $=0.9$ ). It can be accepted to consider the instrument reliable. 
In this study, face validity was established by seeking the perception of hotel employees toward the suitability of the tool and whether it rang true for them or not. Additionally, five human resources hotel managers and six hospitality academicians reviewed the proposed instrument for content validity before it was distributed to hotel employees. Comments and suggestions obtained from the pre-test were used for rewording the instructions and layouts of the questionnaire.

\section{Data analysis}

The Statistical Package for Social Sciences (SPSS) for Windows v.16.0 was used to statistically analyze the data. Mean scores and standard deviations are calculated for all variables in the study. Pearson correlation coefficient was used at a significance level of $5 \%$ to find the relationship between dependent variables and independent variables. Additionally, the hierarchal multiple regression analysis was also used.

\section{Results and discussions}

Sample characteristics

Demographics section involved gender, age, and educational level. Among the 360 hotel employees, $80.5 \%$ of hotel employees were male and $19.5 \%$ were female. About $75 \%$ of hotel employees were aged from 20 to less than 40 years, while approximately $25 \%$ of them were aged from 40 to 55 years. In regards to educational level, the majority of hotel employees (91\%) graduated from university, whereas $9 \%$ of them graduated from high school.

\section{A descriptive analysis of co-workers' warmth and competence items}

In order to identify employees' perceptions of co-workers' warmth and competence, the nine items of these two constructs were descriptively analyzed. They were analyzed by their means and standard deviations (Table 1). The results showed that the mean score of the overall perceived warmth was 2.8. Also, the results showed that the perceived warmth element, i.e. $\mathrm{PW}_{1}$ achieved the highest mean of 3.2, while $\mathrm{PW}_{2}, \mathrm{PW}_{3}$, and $\mathrm{PW}_{4}$ have reported 3, 2.7, and 2.4, respectively. These results indicated that all perceived warmth items had average scores below four, indicating that all traits related to co-workers' warmth (i.e. good-nature; sincerity; warmth; tolerance) were perceived low by employees. It is therefore imperative that hotel management should pay attention to warmth characteristics of the frontline employees, who are in charge of serving customers, because these characteristics are mainly associated with service orientation (Brambilla et al., 2013).

A descriptive analysis of frontline employees' PCSP and turnover intentions items Concerning PCSP, the results clarified that $\mathrm{PCSP}_{1}, \mathrm{PCSP}_{2}, \mathrm{PCSP}_{3}$, and $\mathrm{PCSP}_{4}$ had mean scores of $4.3,4,3.9$, and 3.8, respectively and the mean score of the overall PCSP was 4, indicating that hotel frontline employees as a whole did well in terms of PCSP. Furthermore, the tabulated data indicated that turnover intention items $\left(\mathrm{TI}_{1}, \mathrm{TI}_{2}\right.$, and $\left.\mathrm{TI}_{3}\right)$ achieved mean scores of 2.8, 2.8, and 2.5 , respectively. The mean score of the overall turnover intention was 2.7 as well as all turnover intentions items achieved average scores below 3, indicating that the frontline employees did not have any intention to leave the organization.

Table 1: Cronbach's alpha, means, and standard deviation of all research variables

\begin{tabular}{|l|c|c|c|}
\hline \multicolumn{1}{|c|}{ Research variables } & $\begin{array}{c}\text { Cronbach's } \\
\text { alpha }\end{array}$ & Mean & $\begin{array}{c}\text { Std. } \\
\text { deviation }\end{array}$ \\
\hline \multicolumn{4}{|c|}{ Warmth and competence } \\
Fellow workers' perceived warmth & .901 & 2.8 & .9876 \\
\hline PW $_{1:}$ Frontline employees are good-natured & .901 & 3.2 & .6876 \\
\hline
\end{tabular}




\begin{tabular}{|c|c|c|c|}
\hline $\mathrm{PW}_{2:}$ Frontline employees are tolerant & .901 & 3 & .4836 \\
\hline $\mathrm{PW}_{3:}$ Frontline employees are warm & .911 & 2.7 & .9776 \\
\hline $\mathrm{PW}_{4}$ : Frontline employees are sincere & .887 & 2.4 & .7576 \\
\hline Fellow workers' perceived competence & .887 & 4.4 & .9473 \\
\hline $\mathrm{PC}_{1:}$ Frontline employees are competitive & .887 & 4.6 & .5480 \\
\hline $\mathrm{PC}_{2:}$ Frontline employees are confident & .911 & 4.5 & .9066 \\
\hline $\mathrm{PC}_{3:}$ Frontline employees are intelligent & .901 & 4.3 & .8896 \\
\hline $\mathrm{PC}_{4:}$ Frontline employees are independent & .913 & 4.3 & .6540 \\
\hline $\mathrm{PC}_{5:}$ Frontline employees are competent & .901 & 4.2 & .3770 \\
\hline Proactive customer service performance & .901 & 4 & .7652 \\
\hline $\begin{array}{l}\mathrm{PCSP}_{1:} \text { I check with customers proactively to verify that customer } \\
\text { expectations have been met or exceeded. }\end{array}$ & .911 & 4.3 & .5603 \\
\hline $\begin{array}{l}\text { PCSP }_{2:} \text { I use my own judgment and understanding of product problems } \\
\text { to determine when to make exceptions of improvise solutions. }\end{array}$ & .912 & 4 & .8760 \\
\hline $\begin{array}{l}\mathrm{PCSP}_{3:} \text { I create partnership with other service representatives actively } \\
\text { to better serve customers. }\end{array}$ & .887 & 3.9 & .7650 \\
\hline $\begin{array}{l}\mathrm{PCSP}_{4:} \text { I take the initiative to communicate client requirements to other } \\
\text { service areas and collaborate in implementing solutions. }\end{array}$ & .887 & 3.8 & .8766 \\
\hline Turnover intentions & .901 & 2.7 & .5483 \\
\hline $\mathrm{TI}_{1:}$ I often think about quitting & .901 & 2.8 & .9864 \\
\hline $\mathrm{TI}_{2:}$ I will probably look for a new job & .887 & 2.8 & .7654 \\
\hline $\mathrm{TI}_{3:}$ It is likely that I will actively look for a new job & .912 & 2.5 & .5987 \\
\hline
\end{tabular}

In addition, the results clearly stated that the mean score of the overall perceived competence was 4.4. The results also showed that perceived competence elements $\left(\mathrm{PC}_{2}\right.$ and $\left.\mathrm{PC}_{4}\right)$ had the highest means of 4.6 and 4.5, while $\mathrm{PC}_{1}, \mathrm{PC}_{3}$, and $\mathrm{PC}_{5}$ have reported 4.3, 4.3, and 4.2, respectively. It is clear from table 1 that all competence items achieved average scores above four, indicating that fellow workers' competence was perceived high by employees.

The previous results indicated that frontline employees in hotels were described as competent but cold. According the BIAS map (Cuddy et al., 2011), the low perceived warmth and the high perceived competence of the co-workers in frontline are combined to generate an emotional response (i.e. envy) among hotel frontline employee. This indicates that the frontline employees were highly professional and competitive.

Correlation analysis of perceived warmth and perceived competence with PCSP and turnover intentions

To indicate the relationship between perceived warmth and perceived competence as independent variables and PCSP and turnover intention as dependent variables, a correlation was measured. The results obviously exposed that, there were significant relationships among all these variables. Specifically, perceived warmth had negative relationships with PCSP $\quad(r=0.623-$, Sig. <0.000) as well as with turnover intention $(r=0.342-$, Sig. $<0.000)$.

Table 2: Correlations of perceived warmth with PCSP and turnover intention

\begin{tabular}{|c|c|c|c|}
\hline & & Perceived warmth & PCSP \\
\hline \multirow{2}{*}{$\begin{array}{c}\text { Perceived } \\
\text { warmth }\end{array}$} & Pearson correlation & 1 & $.623-$ \\
& Sig. (2-tailed) & & .000 \\
& $N$ & 370 & 370 \\
\hline \multirow{3}{*}{ PCSP } & Pearson correlation & $.623-$ & 1 \\
& Sig. (2-tailed) & .000 & 370 \\
\hline & $N$ & 370 & Turnover intention \\
\hline
\end{tabular}


International Journal of Heritage, Tourism and Hospitality Vol. (12), No. (1/2), March, 2018 By: Faculty of Tourism and Hotels, Fayoum University

\begin{tabular}{|c|c|c|c|}
\hline $\begin{array}{c}\text { Perceived } \\
\text { warmth }\end{array}$ & $\begin{array}{c}\text { Pearson correlation } \\
\text { Sig. (2-tailed) }\end{array}$ & 1 & $.342-$ \\
& $N$ & 370 & .000 \\
\hline \multirow{2}{*}{$\begin{array}{c}\text { Turnover } \\
\text { intention }\end{array}$} & Pearson correlation & $.342-$ & 370 \\
\hline
\end{tabular}

**Correlation is significant at the 0.05 level (2-tailed).

Table 3: Correlations of perceived competence with PCSP and turnover intention

\begin{tabular}{|c|c|c|c|}
\hline & & Perceived competence & PCSP \\
\hline \multirow{2}{*}{$\begin{array}{c}\text { Perceived } \\
\text { competence }\end{array}$} & Pearson correlation & 1 & .857 \\
& Sig. (2-tailed) & $N$ & .000 \\
\multirow{3}{*}{ PCSP } & Pearson correlation & 370 & 370 \\
& Sig. (2-tailed) & .857 & 1 \\
& $N$ & .000 & 370 \\
\hline \multirow{2}{*}{ Perceived } & Pearson correlation & 370 & $.824-$ \\
competence & Sig. (2-tailed) & 1 & .000 \\
& $N$ & 370 & 370 \\
\hline \multirow{2}{*}{ Turnover } & Pearson correlation & $.824-$ & 1 \\
intention & Sig. (2-tailed) & .000 & 370 \\
& $N$ & 370 & Turnover intention \\
\hline
\end{tabular}

**Correlation is significant at the 0.05 level (2-tailed).

Moreover, table (3) shows that there is a positive relationship between perceived competence and PCSP ( $r=0.857$, Sig. $<0.000$ ). On the other hand, there is a negative relationship between perceived competence and turnover intention ( $r=824-$, Sig. $<0.000)$.

A regression results of perceived warmth and perceived competence with PCSP and turnover intentions

A regression analysis was conducted to identify the effect of perceived warmth on the two dependent variables (PCSP; turnover intention). In addition, the same analysis was used to explore the impact of perceived competence on the dependent variables, as shown in table 4 and 5.

Table 4: Perceived warmth influencing PCSP and turnover intention

\begin{tabular}{|c|c|c|c|c|c|}
\hline \multirow{2}{*}{ Variables } & \multicolumn{2}{|c|}{ Un-standardized Coefficients } & Sig. & \multirow{2}{*}{ Model Statistics } \\
\cline { 2 - 3 } & $\mathrm{B}$ & Std. Error & \multirow{2}{*}{ R-square } & .000 & \multirow{2}{*}{ F: 11.0803} \\
\hline Constant & .615 & .018 & & .000 & \\
\hline PCSP & .095 & .089 & $.425-$ & .000 & \\
\hline Turnover intention & .345 & .056 & $.321-$ & .000 & \\
\hline
\end{tabular}

$*$ Regression equation can be formed as perceived warmth $=.615+.095 \mathrm{PCSP}+.345$ turnover intention

Regarding the variable of perceived warmth, when assessing the influence degree of this variable on PCSP based on the previously mentioned correlation results, it was found to negatively influence the PCSP (R-square =.425-, P-value=.000). Therefore, hypothesis 1 was not supported. This result is contradictory to the study of Amarneh et al. (2010) which found that co-workers' warmth enhanced PCSP. When it comes to turnover intention, it was found to negatively affected by the perceived warmth (R-square $=.321-$, P-value=.001). Therefore, hypothesis 2 was supported. 
This finding was confirmed by a study of Manning et al. (2005) which found that friendliness and warmth lessened turnover intentions. This result also concurs with the two studies of Yang et al. (2012) and Bufquin et al. (2017) which found that the socialization of new employees and coworkers' warmth decreased their intent to leave the hotel profession. Such findings are also supported by attitude theory, which suggests that the cognitive evaluations of work environment and situations come before affective reactions, which sequentially affect individual's intentions and behaviors (Bagozzi, 1992). Hence, if employees perceive that they work with warm colleagues, their turnover intentions should be lessened.

Regarding the variable of perceived competence, when assessing the degree of influence of this variable on PCSP and turnover intention based on the previous correlation results, it was found to positively affect PCSP (R-square $=.752$, P-value=.000) but it was found to negatively affect turnover intention $(\mathrm{R}$-square $=.524-, \mathrm{P}$-value $=.001)$.

Table 5: Perceived competence influencing turnover intention and PCSP

\begin{tabular}{|c|c|c|c|c|c|}
\hline \multirow{2}{*}{ Variables } & \multicolumn{2}{|c|}{ Un-standardized Coefficients } & Sig. & Model Statistics \\
\cline { 2 - 4 } & $\mathrm{B}$ & Std. Error & \multirow{2}{*}{ R-square } & .000 & \multirow{2}{*}{ F: 12.0453} \\
\cline { 2 - 5 } Constant & .143 & .065 & .000 & \\
\hline PCSP & .545 & .098 & .752 & .000 & \\
\hline Turnover intention & .845 & .059 & $.524-$ & .000 & \\
\hline
\end{tabular}

* Regression equation can be formed as perceived competence $=.143+.545$ PCSP +.845 turnover intention

These results are consistent with those of Bufquin et al. (2017) who found that co-workers' competence decreased employees' intentions to quit the hotel. Therefore, hypotheses 3 and 4 were supported. Such findings are also supported by the social exchange theory (SET), which posits that employees are obliged to return a favor after benefiting from another person or group (Blau, 1964). Hence, if employees perceive that they work with competent colleagues, their PCSP is more likely to improve as well as their turnover intentions should be lessened.

Based on the previous regression results, a model has been developed (see Fig. 2). As shown in this figure, there are two important interpretations: (1) perceived competence had a higher negative impact on turnover intentions than perceived warmth; and (2) the competence positively affected PCSP but the warmth negatively affected it. These findings accept with the research of Cuddy et al. (2007) who stated that perceived competence may be more important than perceived warmth and may take primacy in organizational contexts.

Figure 3: Results of hypothesized model

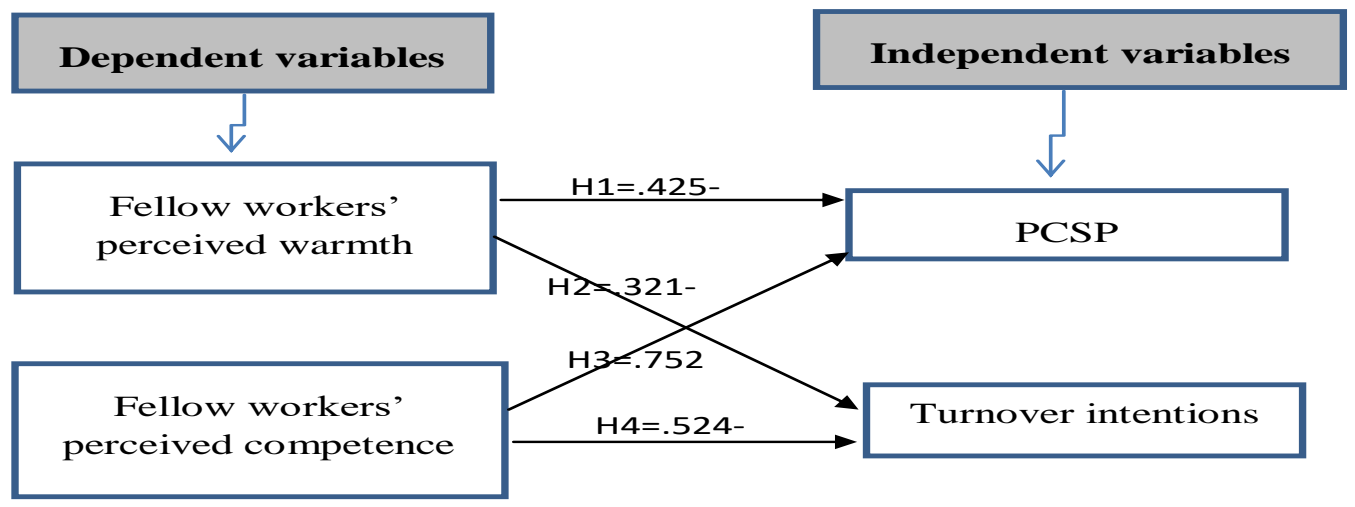




\section{Conclusion and implications}

The study aimed at identifying the effect of perceived warmth and perceived competence on PCSP and turnover intentions. This study could provide useful implications for practitioners: (1) regarding warmth, hotel management should maintain the warmth among the frontline employees despite its negative impact on their PCSP, because it reduces the intention to leave the hotel. However, they should seriously work to reduce the negative impact of the warmth through the continuous controlling and supervision of employees when providing service to customers. Previous studies (e.g. Goodman, 1996; Mill, 2001) confirmed the significant positive impact of the management supervision on the performance of hotel employees; (2) hotel management should also maintain the high level competence of the frontline employees as well as increase it.

\section{Limitations and future research directions}

Several limitations of this study along with its avenues for future research should be noted. First, this study measured only perceived co-workers' warmth and competence. In future studies measuring the employees' perceptions of their managers' warmth and competence would be useful. Second, this research focused only on the frontline employees in front office and food and beverage departments. It would also be beneficial for examining the relationships demonstrated in this study in other hotel departments to indicate to what extent the warmth and competence are critical to hotels. As a closing note, this study examined the effects of the perceived warmth and competence in hotels. Investigating other hospitality settings (e.g., restaurants) by future research is strongly recommended as they also suffer from high staff turnover.

\section{References}

Abele, A. E., \& Wojciszke, B. (2007). Agency and communion from the perspective of self versus others. Journal of Personality and Social Psychology, 93, 751-763.

Abele, A. E., Uchronski, M., Suitner, C., \& Wojciszke, B. (2008). Towards an operationalization of the fundamental constructs of agency and communion: trait content ratings in five countries considering valence and frequency of word occurrence. Journal of Personality and Social Psychology, 38, 1202-1217.

Albattat, A. R. S., \& Som, A. P. M. (2013). Employee Dissatisfaction and Turnover Crises in the Malaysian Hospitality Industry. International Journal of Business and Management, 8 (5), 6271.

Allport, G. W. (1954). The Nature of Prejudice. Boston, Addison Wesley.

Asch, S. E. (1946). Forming impressions of personality. Journal of Personality and Social Psychology, 41, 258-290.

Amarneh, B. H., Al-Rub, R. F. A., \& Al-Rub, N. F. A. (2010). Co-workers' support and job performance among nurses in Jordanian hospitals. Journal of Research in Nursing, 15, 391-401.

Bagozzi, R. P. (1992). The self-regulation of attitudes, intentions, and behavior. Social psychology quarterly, 55 (2), 178-204.

Bales, R. F. (1950). A set of categories for the analysis of small group interaction. American Sociological Review, 15, 257-263.

Birdir, K. (2002). General manager turnover and root causes. International Journal of Contemporary Hospitality Management, 14 (1), 43-47.

Blau, P., (1964). Exchanges and Power in Social Life. John Wiley, New York, NY.

Bowen, D. E. (2016). The changing role of employees in service theory and practice: an interdisciplinary view. Human Resource Management Review, 26 (1), 4-13.

Brambilla, M., Hewstone, M., \& Colucci, F. P. (2013). Enhancing moral virtues: increased perceived out group morality as a mediator of intergroup contact effects. Group Process. Group Processes \& Intergroup Relations, 16, 648-657. 
Bufquin, D. , DiPietro, R. , Orlowski, M., \& Partlow, C. (2017). The influence of restaurant co-workers' perceived warmth and competence on employees' turnover intentions: The mediating role of job attitudes. International Journal of Hospitality Management, 60, 13-22.

Caprariello, P. A., Cuddy, A. J. C., \& Fiske, S. T. (2009). Social structures shapes cultural stereotypes and emotions: a causal test of stereotype content model. Group Processes \& Intergroup Relations, 12(2), 147-155.

Chiang, C. F., \& Jang, S.(2008). The antecedents and consequences of psychological empowerment: The case of Taiwan's hotel companies. Journal of Hospitality \& Tourism Research, 32, 40-61.

Cho, S., Joganson, M. M. , Guchait, P. (2009). Employee intent to leave: a comparison of determinants of intent to leave versus intent to stay. International Journal of Hospitality Management, 28, 374381.

Chuang, C. H., \& Liao, H. (2010). Strategic human resource management in service context: taking care of business by taking care of employees and customers. Journal of Personality and Social Psychology, 63 (1), 153-196.

Cuddy, A. J. C., Fiske, S. T., \& Glick, P. (2007). The BIAS Map: Behaviors from intergroup affect and stereotypes. Journal of Personality and Social Psychology, 92, 631-648.

Cuddy, A. J., Amy J. C., Susan, T., \& Fiske, S. T. (2002). Doddering but dear: Process, content, and function in stereotyping of older persons. In Ageism: Stereotyping and prejudice against older persons. Cambridge, MA MIT Press.

Cuddy, A. J. C., Fiske, S.T., Kwan, V. S. Y., Glick, P., Demoulin, S., \& Leyens, J-Ph. (2009). Stereotype content model across cultures: towards universal similarities and some differences. British Journal of Social Psychology, 48, 1-33.

Cuddy, A. J., Fiske, S. T., \& Glick, P. (2008). Warmth and competence as universal dimensions of social perception: the stereotype content model and the BIAS map. Journal of Social Psychology, 40, 61-149.

Cuddy, A. J., Glick, P., \& Beninger, A. (2011).The dynamics of warmth and competence judgments, and their outcomes in organizations. Journal of Organizational Behavior, 31, 73-98.

Cuddy, A.J. C., Kohut, M. , \& Neffinger, J. (2013). Connect then lead. Harvard Business Review, 2-9.

Fiske, S.T., Cuddy, A. J. C., \& Glick, P. (2007). Universal constructs of social cognition: warmth and competence. Trends in Cognitive Sciences, 11 (2), 77-83.

Fiske, S.T., Cuddy, A. J. C. \& Glick, P. (2006). Universal dimensions of social cognition: warmth and competence. Trends in Cognitive Sciences, 11(2), 77-83.

Fiske, S. T., Cuddy, A. J. C., Glick, P., \& Xu, J. (2002). A model of (often mixed) stereotype content: competence and warmth respectively follow from perceived status and competition. Journal of Social Psychology. 82 (6), 878-902.

Fiske, A. P., Kitayama,S., Markus, H. R., \& Nisbett, R. E. (1998).The cultural matrix of social psychology. Cited in. The Handbook of Social Psychology, 2, 915-981.

Goodman, R. (1996). The management of service for the restaurant manager. $2^{\text {th }}$ ed. London, Irwin, Inc. company.

Harris, L. T., \& Fiske, S. T. (2009). Social neuroscience evidence for dehumanized perception. Journal of Social Psychology, 20, 192-231.

Harris, L. T., \& Fiske, S. T. (2006). Dehumanizing the lowest of the low: Neuro-imaging responses to extreme outgroups. Journal of Psychological Science, 17, 847-853.

Jang, J., \& George, R. T. (2012). Understanding the influence of polychronicity on job satisfaction and turnover intention: a study of non-supervisory hotel employees. International Journal of Hospitality Management, 31(2), 588-595.

Jung, C. S. (2014). Why are goals important in the public sector? Exploring the benefits of goal clarity for reducing turnover intention. Journal of Public Administration Research, 24, 209-234. 
Jung, H. S., Yoon, H. H., \& Kim, Y. J. (2011). Effects of culinary employees' role stress on burnout and turnover intention in hotel industry: moderating effects on employees' tenure. Journal of Services Research, 32 (13), 2145-2165.

Karatepe, O. M. (2013). The effects of work overload and work-family conflict on job embeddedness and job performance. Journal of Contemporary Hospitality Management, 25 (4), 614-634.

Kassin, S. M., Fein, S., \& Markus, H. R. (2011).Social psychology. $8^{\text {th }}$ ed.Belmont, Ca,Wadsworth,Cengage Learning,Inc.

Kennedy, D. J., \& Berger, F. (1994). Newcomer socialization: oriented to facts or feelings?. Cornell Hotel and Restaurant Administration Quarterly, 35(6), 58-71.

Kim, H. J., Tavitiyaman, P., \& Kim, W. G. (2009). The effect of management commitment to service on employee service behaviors: The mediating role of job satisfaction. Journal of Hospitality \& Tourism Research, 33, 369-390.

Kim, W. G., Lee, Y.-K., \& Yoo, Y.-J. (2006). Predictors of relationship quality and relationship outcomes in luxury restaurants. Journal of Hospitality \& Tourism Research, 30, 143-169.

Lam, T., Pine, R., \& Baum, T. (2003). Subjective Norms Effects on Job Satisfaction. Annals of Tourism Research, 30 (1), 160-177.

Lashley, C. (2001). Costing staff turnover in hospitality service organizations. Journal of Services Research, 1 (2), 3-24.

Lau, P., Tong, J. L. Y., Lien, B. Y. H., \& Hsu, y. (2017). Ethical work climate, employee commitment and proactive customer service performance: Test of the mediating effects of organizational politics. Journal of Retailing and Consumer Services, 35, 20-26.

Leach, C. W., Ellemers, N., \& Barreto, M. (2007). Group virtue: The importance of morality (versus competence and sociality) in the positive evaluations of in groups. Journal of Personality and Social Psychology, 93, 234-249.

Manning, M. L., Davidson, M., \& Manning, R. L. (2005). Measuring tourism and hospitality employee workplace perceptions. International Journal of Hospitality Management, 24, 75-90.

Mill, R. (2001). Restaurant management customers, operations, and employees. $2^{\text {th }}$ ed. New Jersey, Prentice-Hall.

Nunnally, J. C., \& Bernstein, I. H. (1994), Psychometric Theory. New York, McGraw-Hill.

Pallant, J. (2007). SPSS survival manual: A step by step guide to data analysis using SPSS for windows. $3^{\text {th }}$ ed. New York, McGraw Hill.

Peeters, G. (2001). In search for a social-behavioral approach-avoidance dimension associated with evaluative trait meanings. Psychologica. Belgica, 41(4), 187-203.

Peeters, G., \& Czapinski, J. (1990). Positive-negative asymmetry in evaluation : The distinction between affective and informational negativity effects. European Review of Social Psychology, 11 , 3360.

Peeters, G., Cornelissen, I., \& Pandelaere, M. (2003). Approach-avoidance values of target-directed behaviours elicited by target-traits: The role of evaluative trait dimensions. Current Psychology Letters: Behaviour, Brain \& Cognition, 11, 1-10.

Rank, J., Carsten, J. M., Unger, J. M., \& Spector, P.E. (2007).Proactive customer service performance: relationships with individual, task, and leadership variables. Journal of Human Performance, 20 (4), 363-390.

Raub, S.P., \& Liao, H. (2012).Doing the right thing without being told: joint effects of initiative climate and general self-efficacy on employee proactive customer service performance. Journal of Applied Psychology, 97 (3), 651-667.

Robbins, S., \& Judge, T. A. (2007). Organizational behavior. $12^{\text {th }}$ ed. New Jersey, Prentice-Hall.

Rosenberg, S., Nelson, C., \& Vivekananthan, P. S. (1968). A multiconstructal approach to the structure of personality impressions. Journal of Social Psychology, 9, 283-294. 
Singh, J., Verbeke, W., \& Rhoads, G. K. (1996). Do organizational practices matter in role stress processes? A study of direct and moderating effects for marketing-oriented boundary spanners. Journal of Marketing, 60, 69-86.

The Egyptian Hotel Guide. (2016). $34^{\text {th }}$ ed. Cairo, Egyptian Hotel Association.

Tracey, J. B., \& Tews, M. J. (2004). An empirical investigation of the relationships among climate, capabilities, and unit performance. Journal of Hospitality \& Tourism Research, 28, 298-312.

Wojciszke, B. (2005a). Affective concomitants of information on morality and competence. Journal of European Psychologist, 10 (1), 60-70.

Wojciszke, B. (2005b). Morality and competence in person and self-perception. European Review of Social Psychology, 16 (1), 155-88.

Wojciszke, B. (1994). Multiple meanings of behavior: construing actions in terms of competence or morality. Journal of Social Psychology, 67, 222-232.

Wojciszke, B., \& Andrea, E. A. (2008). The primacy of communion over agency and its reversals in evaluations. European Journal of Social Psychology, 38 (7), 1139-1147.

Wojciszke, B., Bazinska, R., \& Jaworski, M. (1998). On the dominance of moral categories in impression formation. Journal Social Psychology, 24 (12), 1251-1263.

Yang, J. T., Wan, C. H., \& Fu, Y. J. (2012). Qualitative examination of employee turnover and retention strategies in international tourist hotels in Taiwan. International Journal of Hospitality Management, 31 (3), 837-848.

Zhu, H., Lyub, Y., Dengc, X., \& Yed , Y. (2017). Workplace ostracism and proactive customer service performance: A conservation of resources perspective. International Journal of Hospitality Management, 64, 62-72.

Bolch, M. (2001).The coming Crunch; Human Resource Training Magazine, April 196(2628), 42-46.

Carley, K. (1992). Organizational learning and personnel turnover.Organ. Sci.3 (1) 20-46.

Cascio, W. (2002). Responsible Restructuring: Creative and Profitable Alternatives to Layoffsl, San Francisco: Berrett-Koehler.

Chiu, C.-K., Lin, C.-P., Tsai, Y. H., \& Hsiao, C.-Y. (2005). Modelling turnover intentions and their antecedents using the locus of control as a moderator: A case of customer service employees. Human Resource Development Quarterly, 16(4), 481-499.

Fortino, P. \&Ninemeier, J. (1996)."Industry in the dark about turnover rate", Lodging, Vol. 22 (No.4), pp.25.

Gall, M. D., Gall, J. P., \& Borg, W. R. (2006). Educational research: An introduction (8th Ed.). Pearson Education Inc. ISBN-10: 0205488498.

Glebbeek, A.C., Bax, E.H. (2004). Is high employee turnover really harmful; An empirical test using company records, Academy of Management Journal, Vol. 47 (No.2), pp.86-277.

Gregory, R.J. (2014). Psychological Testing: History, Principles and Applications. (8th Ed.). Allyn and Bacon: Boston.

Gupta, N. and Shaw, J. (2001). Pay fairness and Employee outcomes. Exacerbation and attenuation effects of financial needs.Journal of Occupational and Organizational Psychology Vol 74 (3), pp 22.

Hilton Hotels Corporation Journal (2003). Vol. 1, No. 6, pp 8-12.

Hinkin,T.R\&Tracey,J.B. (2000). The cost of turnover, The Cornell HRA Quarterly .page 14-21.

Judge, T. A., Thoresen, C. J., Bono, J. E., \& Patton, G. K. (2001). The job satisfaction-job performance relationship: A qualitative and quantitative review. Psychological Bulletin.

Kusluvan, S. (2003). Multinational enterprises in tourism; A case study of Turkey. Unpublished doctoral dissertation, Strathclyde University, the Scottish Hotel School, Glascow.

Mugenda, O.M and Mugenda, A.G (2008). Research Methods, Quantitative \& Qualitative Approaches, Acts Press, Nairobi.

Ready, D. A., Hill, L. A., \& Conger, J. A. (2008).Winning the Race for Talent in Emerging Markets. Nov 2008. Harvard Business Review. 
Sahinidis, G., and Bouris, J. (2008). "Employee perceived training effectiveness relationship to employee attitudes". Journal of European Industrial Training, 32(1), 63-76.

Schermerholn, JR. (1996). Essentials of management and organizational behavior, NY: John Wiley and Sons, New York.

Tanke, ML. (2001). Human Resources Management for the Hospitality Industry, 2nd ed., Thomson Learning, Albany, NY.

Taylor, S. (2002). People and Organization Employee Resourcing.Prentice-Hall, Sidney; Australia.

Van Dick, R., Christ, O., Stellmacher, J., Wagner, U., Ahlswede, O.,

Grubba, C., Hauptmeier, M., Hohfeld, C., Moltzen, K., \&Tissington, P. A. (2004). Should I stay or should I go? Explaining turnover intentions with organizational identification and job satisfaction.British Journal of Management, 15, 351- 360.

WeiBo, Z., Kaur, S., \&Zhi, T. (2010). A critical review of employee turnover model (1938-2009) and development in perspective of performance.African journal of Business Management, 4(19), 4146-4158.

White, G.L (1995). Employee turnover; the hidden drain on profits; HR Focus, Vol.72 (No.1) pp.15-17.

Willis, M. (2002). 'Reducing Employee Turnover', Creating Quality Newsletter, Vol. 11, No. 5, viewed 25 October 2016, http://www.missouribusiness.net/cq/2002/reducing_employee_turnover.asp.

Woods, R H (1999). 'Predicting is difficult, especially about the future: human resources in the new millennium', International Journal of Hospitality.

Zuber, A. (2001). "A career in food service cons: high turnover", Nations Restaurant News, Vol. 35 (No.21), pp.147-148. 